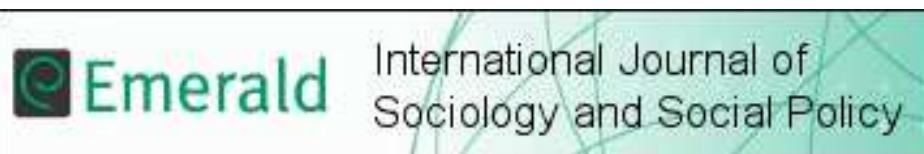

\title{
Informal economy, informal state: The case of Uzbekistan
}

\begin{tabular}{|r|l|}
\hline Journal: & International Journal of Sociology and Social Policy \\
\hline Manuscript ID: & IJSSP-05-2011-0031 \\
\hline Manuscript Type: & Original Article \\
\hline Keywords: & informal economy, Central Asia, Uzbekistan, state, corruption \\
\hline \multicolumn{2}{r}{} \\
\end{tabular}

SCHOLARONE ${ }^{m}$

Manuscripts 


\begin{abstract}
In the Soviet Union, the official command structure for economic production and distribution gave rise to, and depended upon, what has been described as a 'shadow' economy. In the postsocialist context, the unregulated, often extra-legal activities of production and exchange, encompassing the survival strategies of the poor, the emergence of postsocialist 'Mafias', and much entrepreneurial activity, has been described using the concept of the 'informal economy'. This article argues that what we might think of as informal economic activity in Uzbekistan cannot be understood in relation to a formal economy, but is rather an expression of a more general informalisation of lifeworlds following the end of the Soviet Union. Unlike the situation in the Soviet Union, the informal does not emerge from and exist in relation to formal political and economic structures. The state itself is experienced in personalised terms, as a 'Mafia', and the informal is all that there is. If the concept of the informal depends on the existence of the formal, how useful is the term informal economy in a context like Uzbekistan? Where the state no longer provides a formal structure in practice, this is sought in moral ideals of state and community.
\end{abstract}

The origin of the term informal economy has been attributed to papers written by the anthropologist Keith Hart in the early 1970s. ${ }^{1}$ He used it to refer to the irregular income earning opportunities of the urban poor in Ghana. In the typology he worked out at the time, formal income opportunities were made up of public and private sector wages and transfer payments, while informal opportunities encompassed the wide range of activities which fell outside the organised labour force. These included activities such as farming and market gardening, self-employed commodity production, petty trade, smuggling, theft and prostitution (Hart 1973).

For some time, informal economic activity has come to be understood in much broader terms than the survival strategies of sections of the urban poor in the 'less developed

\footnotetext{
${ }^{1}$ This article is a substantially revised version of material previously published as a working paper (Rasanayagam 2003)
} 
world'. The concept of 'informalisation' developed by Castells and Portes has been influential. They have described an expanding informalisation, both in poorer and wealthy economies, characterised by, among other things, decentralisation of networks of production and distribution, and the use of subcontracting to replace unionised labour in ways which enable corporations to take advantage of unregulated activities in a regulated environment. The informal economy in their analysis encompasses the illegal or unregulated activities of individuals struggling to make ends meet, but equally those of informal entrepreneurs and some of the activities of transnational corporations (Castells \& Portes 1989). An important insight has been that there is no neat separation between a formal, state regulated and an informal, unregulated sector, as the latter is shaped in important ways by state regulation and integrated within transnational networks of production and exchange, something that a number of anthropologists have explored ethnographically (Mollona 2005; White 1994). Hart himself has revisited his earlier work, describing the informal economy in broader terms as 'a market-based response of the people to the overweaning attempts of bureaucracy to control economic life from above' (Hart 1992: 223).

Many of these insights have been confirmed in analysis of Soviet and postsocialist societies. In the context of the Soviet Union, a distinction has typically been made between the 'state' or 'official' economy, the production of goods and services within the socially owned sector subject to central planning, and the 'unofficial' or 'shadow' economy, activities undertaken by individuals for private gain, both legally sanctioned and illicit, which were not subject to the central planning process (Grossman 1977; Treml \& Alexeev 1994). Here, the distinction is embedded in the ideological and institutional framework within which economic activity took place. At the same time, a number of observers have pointed out that it is impossible to draw a clear distinction between state and shadow economies, since they were each dependent upon the other and in fact formed two aspects of a single economy (Humphrey 1998: 146f.; Kotkin 1995:274).

In the postsocialist context, analysis has been in terms of informal rather than shadow or second economies (Johnson et al. 1997; Kurkchiyan 2000; Rodgers \& Williams 2009; Sik 1992). This literature has pointed to how informal economies have grown out of the specific circumstances of the economic, political, and social transformations. Postsocialist informal economies are described in terms of the survival strategies of individuals struggling to make ends meet in the face of economic collapse and the withdrawal of state welfare and employment provision. They also encompass the activities of entrepreneurs operating outside the formal legal and regulatory structures, and the criminal and 'Mafia' activities which have 
expanded in many post-Soviet republics. As in the Soviet Union, postsocialist informal economies are not distinct, self contained spheres of economic activity and exchange. In a previous article I described how in post-Soviet Uzbekistan the business and income generating activities of individuals, households and larger enterprises cannot easily be categorised as being distinctly formal or informal (Rasanayagam 2002).

In this article I argue that in Uzbekistan the informal economy is not simply embedded in or linked with a formal one. Rather, what we might think of as informal economic activity is just one expression of a more general informalisation of state, society and lifeworlds following the collapse of the Soviet Union. In the Soviet Union, state production plans could not have been fulfilled without the informal activities of enterprise managers and workers. The formal and the informal were organically linked within the everyday lives of Soviet citizens. Nevertheless, the state provided a clear ideological and material structure in relation to which informal activities and exchanges emerged, and gave those informal activities their distinctive character. In Uzbekistan, this structure no longer exists, as the state itself has become simply a 'Mafia' in the words of many of those I encountered during research. The concept of the informal economy implies a corresponding formal structure and practice of regulation and exchange. As Castells and Portes have put it, 'it is only because there is a formal economy (i.e., an institutional framework of economic activity) that we can speak of an 'informal' one' (Castells \& Portes 1989:13). The term 'informal economy' carries with it the connotation of being abnormal, or exceptional to the rule in some way. In Uzbekistan, informalisation has become the rule, with no formal counterpart except in moral ideals of community and state expressed by many I encountered during field research.

An examination of what we might view as informal economic activity exposes the informal nature of the state itself. By 'the state', I am not referring to institutional structures or welfare provision. Rather, I explore how the state becomes an object within the experience of citizens. A number of anthropologists have criticised the notion that the state is an objective, material realty, existing above and beyond the individual. The seeming reality of the state, they have argued, is an ideological project of domination (Abrams 1988) or, following a Foucault inspired analysis, a structural effect produced within relations of power (Mitchell 1999). The state is not a 'thing', then, but nevertheless takes shape, albeit contingently and situationally, through material phenomena, objects, institutions, and relations (Harvey 2005). Located and contingent instantiations the state emerge within the everyday experience of people engaging in transactions of one sort or another; in the 
particular constraints and possibilities, risks and opportunities, of setting up and running business ventures, in obtaining land from a collective farm to use for private plot production, or in the encounters that a marshrutka taxi driver negotiates with traffic policemen on his route.

Akhil Gupta has argued that the discourse of corruption is an arena where the state, as well as the idea of what it is to be a citizen, is imagined and constituted. How people talk about corruption, what they classify as corruption, and the moral categories into which they place acts which could be viewed as corruption, independent of their formal legality, is important for understanding how people conceptualise the boundaries of the state and themselves in relation to it (Gupta 1995). The study of corruption in postsocialist societies has proved a productive site for exploring the moral evaluations of transforming political and economic circumstances and imaginings of moral personhood and community (Polese 2008; Sneath 2006; Werner 2000). This article explores the state in Uzbekistan that emerges within the experience of individuals as they engage in informal economic activities. It explores how discourses on corruption are a site of moral reasoning where individuals reflect on this experience, and develop and contest conceptions of legitimate governance and ideals of state and moral community.

This article is based on two periods of field research in Uzbekistan. The first was conducted in the city of Andijan and a nearby village I am calling Pakhtabad from 19982000. The second was for 10 months in the city of Samarkand and Pakhtabad, between 2003 and 2004. The language of communication was predominantly Uzbek, with Russian in Andijan and Samarkand cities. The research was undertaken through what anthropologists tend to gloss as 'participant observation'. However, this is an inadequate or even misleading description of what anthropologists do 'in the field'. One of the most satisfying accounts of the nature of anthropological knowledge, and of the doing of anthropological research, that I have come across is Michael Carrithers' description of anthropology as a moral science of possibilities (Carrithers 2005). Carrithers describes fieldwork as an engaged learning, an opening up to the rationalities and moral perspectives of others. It is an embodied practice which is constituted not so much by the discovery of facts and the gathering of data, but by the labours, rigours, embarrassments and adjustments of the engaged learner. Anthropological research is a sharing of perspectives, where the anthropologist inhabits alternative lifeworlds and moral frames, possibilities for being and conceiving the world. The 'truth' of the research I have conducted in Uzbekistan is not founded on a notion of statistical significance, where surveys or interviews with a limited group of informants can stand for a 
wider population. What I aspire to is a decentring of the categories we tend to think with, and to suggest alternative possibilities for how we might conceive of, and act within, the world.

\section{The context of Uzbekistan}

Since Uzbekistan became independent in 1991 a number of economic reforms have been implemented. Consumer prices have been largely liberalised, small scale enterprises, particularly those in the retail sector, and some larger ones have been privatised as well as most of the housing stock, and entrepreneurial activity is now legal. As a result there has been a mushrooming of petty commodity production and trade activity, such as shoe and knife making, private retail shops and stalls and other micro businesses. However, the central government retains a large measure of control over strategic sectors of the economy. Cotton has historically been an important export crop for Uzbekistan and state procurement plans continue to be issued for its delivery by collective farms, as well as for wheat. State monopolies are maintained over strategic commodities such as gold, oil and gas, as well as over the processing of raw cotton, and the central government retains effective control over large enterprises even if they have been partly privatised. In general, petty commodity production and trade conducted at the level of a single individual or household has developed greatly since independence, while larger enterprises and the large scale exploitation of resources are subject to varying degrees of central government control. High taxes and levels of regulation effectively force any business or enterprise between these extremes to operate with some degree of illegality (Rasanayagam 2002).

Small businesses engage in a combination of legal and illegal transactions and I was often told by traders and entrepreneurs that it was impossible to operate completely within the law at all times. The following case of a privately run oshkhona (a cafeteria-type restaurant serving Uzbek cuisine) is an example. The owner of this oshkhona reported how a gas inspector only gave him authorisation to operate two gas fired cauldrons instead of the four needed so that he could collect bribes to ignore the operation of the other two. The owner claimed that he paid a patent for some of his employees, the two main cooks, but not for the other workers who were thus employed illegally. ${ }^{2}$ In addition, he had been refused a licence to run the oshkhona until he paid a bribe of US\$1000 to the city hokim (governor) or his deputy which he had not done, so he was operating without official registration. While the oshkhona was operating openly and the owner was acting within the law in many respects, at

\footnotetext{
${ }^{2}$ A patent is a tax in the form of a fixed monthly fee. Micro business run by one person or household (fizicheskoe litso) pay this form of tax, and by law a patent must be paid for each worker in the café.
} 
the same time a large part of his business was technically illegal. This ambiguous status was largely engineered by the state regulatory officials themselves.

It is impossible to distinguish between clearly defined informal and formal economies. More than this, in Uzbekistan the informal character of economic activity is an expression of a more general informalisation of lifeworlds, one which is no longer defined in relation to a 'formal' sphere of governance or economy. In the following section I will describe the nature of these lifeworlds, and the section after that discusses the informalised nature of the state itself. This will be discussed in relation to the situation in the Soviet past where the informal emerged from a formal political and economic structure. The final section will discuss the moral ideals of state and community expressed in discourses of corruption.

\section{Informalised lifeworlds: Household, land, and the collective farm}

Tohirjon is a teacher in one of the schools in the village of Pakhtabad in the Fergana Valley. ${ }^{3}$ He was in his mid-to-late 30s at the time of my research, and was the head of his household, which consisted of his wife, their four daughters, and his mother. His brothers had married and settled in their own separate household compounds. His household income was made up of a number of sources, as is typical in the village, including his salary from teaching in the school, his mother's pension, child support payments, private English classes to coach students to pass the university entrance examinations, production from land he had obtained as household plots from the collective farm (amounting to about a quarter of a hectare by 2004), and raising bull calves for sale as beef. Salaries from state jobs such as teaching are low (Tohirjon's salary from the school was \$20), and need to be supplemented with other sources of income. Agricultural production is an important element of this in rural areas (Rasanayagam 2002). In Torhirjon's case, it made up around $70 \%$ of his household income in 2000, although on my second visit in 2004 this was much less profitable and his private teaching had become more significant.

An account of Torhirjon's efforts to secure land plots from the collective farm is illustrative of the 'informal' nature of income generating activities, and how the state emerges within this experience. According to the Law on Dehqon farming of 1998 (articles 7 and 8) all those employed on a collective farm, as well as doctors, teachers and other specialists, are entitled to be granted household plots (priusadebnyi zemel'nyi uchastok in Russian, tomorqa in Uzbek) of up to 0.35 of a hectare from collective farm land. The actual amount allocated is

\footnotetext{
${ }^{3}$ All names are pseudonyms, as is the name of the village.
} 
left up to the local collective farm and local government authorities Although this land continues to be publicly owned, villagers have use rights over the plots for their lifetime which can be passed on to their descendants. People talked about household plots as if they were their own property. In addition, in Pakhtabad land was rented from the collective farm for a few months after the wheat harvest in June, when production for the state plan has been completed, until the next planting of wheat or cotton in late autumn, and villagers approach the brigadiers directly for this land. ${ }^{4}$

In 1998 Tohirjon approached the collective farm chairman for an extra 10 sotok $(0.1$ of a hectare) as a household plot since people are entitled to this upon marriage. At the time, he had 6 sotok attached to his household compound which had previously been his parents' home. He was refused on the grounds that since he lived in the parental household he would not need an extra plot to build a new house. Sometime later he met a member of the viloyat (provincial) land commission by chance at a bus stop in a neighbouring village, and as they chatted it turned out that the commissioner came from the same village as one of Tohirjon's work colleagues. Tohirjon told him about his need for an extra plot and the commissioner agreed to help. Six months later, the commissioner's brother, who was also a member of the land commission, visited Tohirjon and agreed to arrange for him to be granted land for a bribe of 50,000 Sum (about $\$ 100$ at the time) for 10 sotok. The commissioner arranged things with the collective farm chairman, district and provincial authorities and in the end Tohirjon received 8 sotok for which he paid 40,000 Sum. This land was registered at the Village Committee (the lowest state administrative unit) in his name for land tax purposes. In this transaction what is being 'bought' for the bribe is the official registration of this land as Tohirjon's household plot (priusadebnyi uchastok/tomorqa).

The next year he and many other villagers were approached by the collective farm management offering to sell more land (these were extra-judicial transactions) and this time he paid 85,000 Sum for two 10 sotok plots. Before this land was registered with the Village Committee, however, the collective farm chairman was replaced and the new chairman, under pressure to fulfil the state production plan for cotton and wheat, threatened to reclaim all the land which had been illegally sold. Because of the large number of people involved who had all paid substantial amounts of money (I was told that about 500 people had bought land in this way, although details were hard to verify) he did not immediately reclaim the land, but reduced the plot allotments from 10 to 6 sotok, and froze the granting of further

\footnotetext{
${ }^{4}$ Deniz Kandiyoti has written extensively on different strategies by which people gain access to land in Uzbekistan (Kandiyoti 1999; 2002; 2003).
} 
household plots for married couples. The Village Committee was refusing to register the land in the new owners' names so they had no formalised legal claim on it. This affair was not restricted to the collective farm management as sellers and villagers as buyers. Decisions to transfer land to use as household plots must be ratified by the district and provincial government authorities so the relevant officials in those bodies also had to be involved, as the involvement of the viloyat land commission officials indicates, and the Village Committee had to register the land in the villagers' names. During my second visit to the village in 2004 Tohirjon was once more in negotiations to 'purchase' more land, another 6 sotok, for $\$ 400$, and I was told that the farm and local government authorities were in the process of regularising the previous illegal transfers by gradually registering the land officially as household plots.

These transactions need to be placed in the wider context of land use on this collective farm. According to its former chief accountant who had retired in 2000, before independence in 1991 the collective farm comprised around 2500 hectares but in 2004 it directly controlled only about 600 hectares. Over the years, most of its land has been distributed, either in the form of household plots or different types of private farming contracts. ${ }^{5}$ The latter, covering about 1500 hectares according to the former accountant, include a large livestock farm of over 300 hectares which has been granted on the basis of a long term lease, and numerous smaller farms which lease up to 4 hectares. Private commercial farms do not have free use of this land but are contractually obliged to fulfil the production plan handed down by state authorities to the collective farm to produce wheat or cotton. As Tommaso Trevisani has shown, the de-collectivisation process in Uzbekistan, which has ostensibly aimed at a greater commercialisation of agricultural production, has not diminished central government control but only made it a little more indirect (Trevisani 2009).

In 2001 the collective farm was converted into a shirkat. This represents a transformation in the structure of accountability. The direct hierarchy of command and control inherited from the Soviet system, where production plans were passed down from the centre to regions and ultimately to state and collective farms, has been replaced by a 'contract' system which is equally accountable to central planning. The farm's central administration became the main shirkat, responsible for fulfilling the state delivery plan for cotton and wheat, and subcontracts production to the brigades which have themselves become smaller shirkat. In turn, the 'brigade' shirkat distribute similar contracts to individual

\footnotetext{
${ }^{5}$ For accounts of agricultural reforms see Trevisani (2009) and Ilkhamov (1998).
} 
households, supplying all non-labour inputs while the households provide labour and deliver a contracted amount of produce.

The former collective farm accountant admitted that there are far too many workers to be supported by the limited land remaining in the shirkat. There were around 2000 villagers registered as farm workers, and each household needed to be given at least some land. Most have around 0.3 of a hectare to manage. The example of how a brigade leader managed his land just before the transition to a shirkat is illustrative. This brigade was responsible for farming 35 hectares of land (16 for wheat and 19 for cotton at the time of my research) and had 80 people officially on its books. However, only four of these worked full time. These were the only workers within the brigade who were able to make a significant income from the land as they were each allocated four hectare plots on which to grow wheat by contract. It is worthwhile looking after the large wheat plots as the worker can keep any wheat in excess of the contracted amount to be delivered at the relatively low state price, and a full time worker told me that he had received two tons of surplus wheat in this way, worth about 160,000 Sum $(\$ 320)$ on the open market.

Working cotton land is not so profitable, however. The brigade leader divided this land among his part-time workers, mostly women, in small, 0.2 or 0.3 hectare plots so that everyone had at least some land to work. Cotton land was ploughed, planted and fertilised as a unit by the brigade's full time workers using tractors while the part time workers were responsible for the manual work of weeding and harvesting cotton on the small plots allocated to them. The benefits from working such plots are minimal. Workers earned a small income from harvesting the cotton (usually about $\$ 10$ for the whole harvest), and they had the right to use the cotton plant stalks for winter fuel. Within the collective farm wages are not paid in cash, but recorded in cash terms and this can be used as credit to pay gas, electricity and other utilities charges. Workers also typically received a sack of wheat $(50 \mathrm{~kg})$ and other vegetables such as onions or potatoes for the year's work.

An important incentive for people to work within the collective farm despite low returns was that in order to qualify for child support and other state benefits people have to be employed in an official organisation, although these payments are very small. Moreover, undertaking collective farm work did not take time away from other occupations. Part time workers I interviewed estimated that their official work on the farm took up only about 50 days a year outside the harvest period, and as it is shared by all the women in the household it does not stop people from engaging in other income generating or subsistence activities. When I asked an older female worker why she continued to work for such little return, she 
replied that the cotton stalks she collected at the end of harvest would be enough for most of her household's winter heating and cooking needs, and that if she was busy her kelin (daughter-in-law) could do the work for her. This is comparable to a study of a village in neighbouring Fergana province undertaken by the Russian anthropologist Sergei Abashin, who found that during the 1990s the collective farm he studied employed 2000 workers, out of a total work-age population of the village of 5000. Of these 2000 only 60 were full time, working over 300 days a year. The remainder worked only two to three months on the collective farm (Abashin 1997).

Households adopt a multi-stranded strategy which incorporates work in the collective farm (or by contract to the shirkat as it has become), in other state institutions or enterprises such as one of the village schools, or in the private cotton processing plant located next to the village. In addition to agricultural production on household plots for sale and home consumption, a household will typically also engage in a range of income generating activity. Craft production such as shoe making, leather tanning or knife making is common in Pakhtabad. Such enterprises are run by an usta (master craftsman) with a number of shogird (apprentices) who work for little or no pay. Many villagers are house builders and decorators or carpenters and work locally, in Tashkent, or in neighbouring countries. Other ventures include small shops, chicken farms with up to 200 hens for egg production, cotton seed oil production, or small scale flour mills. People who engage in trade either transport agricultural produce, mainly tomatoes, peppers, and fruit, to Kazakhstan, Kyrgyzstan or Russia, or buy consumer goods from Tashkent or neighbouring countries for resale locally. A significant savings and investment strategy is the raising of livestock, mainly bull calves for sale as beef. These goods and services are sold directly in local bazaars or through middlemen.

Even during the Soviet period, when the collective farm was a much larger economic and political presence and most households contained at least one member who was a farm worker, villagers were not completely dependent on their official income. Working from survey data on household expenditure in Osh oblast, Kyrgyzstan in 1988, the Russian ethnologist Segrei Poliakov estimates that $70 \%$ of the population made a living within the non-state, unregualted economy (Poliakov 1992:89-90). He states that a large proportion of Central Asia's rural population took no part in public production in collective and state farms and other state enterprises. In the Karl Marx state farm in Leninabad Oblast in the Tajikistan part of the Fergana Valley only 650 such jobs were available among a working population of 20,000 . On the basis of this he deduces that $85 \%$ must have been engaged primarily in private commodity production (Poliakov 1992:42). Villagers in Pakhtabad claimed that before 


\section{The informalised state in Uzbekistan}

Of course, what has been called the shadow or second economy was a well documented feature of Soviet society. A number of observers have also shown that it was not a distinct and separate sphere, but the 'second economy' and the centrally planned structures of production and distribution were integral to one another (Humphrey 1998; Kotkin 1995; Rasanayagam 2002). However, in the Soviet Union a clear vision of citizen and state was nevertheless expressed in official discourse and enacted in social and material provision. The Soviet state was a transformative and totalising project which aimed to reshape not only the economic system and society, but also the human person. The ideal of the Soviet citizen was not the autonomous individual of the liberal Western imagination, but entered society as a member of a collective, for example a work collective or a class group in school or university. All able bodied citizens were obliged to work in the social sector, in a state enterprise or cooperative integrated within the structures of central planning. Those who existed independently were positioned outside of this vision and were officially termed parasites, for example 'speculators' who traded outside the official distribution networks, or teachers who gave private lessons to children to pass entrance exams. The work collective 
was itself a total social institution, providing facilities for art and cultural activities, sport, holidays, special interest clubs and tourist trips (Zinoviev 1984). They were a means to fashion a socialist moral subject who embodied collective goals and values and was committed to building a socialist society (Hoffmann 2003; Kharkhordin 1999).

This is not to say that the New Soviet Person became a reality, that state discourse was indeed internalised by Soviet citizens. Numerous studies have described the informal, unregulated circulation of goods and services within circles of friendship and acquaintance (Ledeneva 1998), or the more extractive practices of bribery and tribute taking which operated within hierarchies of Party, state and enterprise (Lubin 1984; Zemtsov 1976). A disjuncture between a public performance in line with the dominant state discourse and an alternative private stance became commonplace (Kharkhordin 1999; Kotkin 1995). Alexei Yurchak has made the important observation that this did not necessarily express or imply opposition to the Soviet state, but is better understood as what he calls 'deterritorialisation' in relation to the state's authoritative discourse. By a public performance, individuals reproduced themselves as proper Soviet citizens, which allowed them to occupy an alternative sociality, often in work-places, clubs and societies which were themselves enabled by the official Soviet state structures (Yurchak 2006). In the Soviet Union, the second economy emerged from, and was in a mutually dependent relation with, the official structures of central planning, production and distribution. In a similar way, the alternative socialities occupied by Soviet citizens were enabled by the authoritative discourse of the Soviet state and its practical application.

In post-independence Uzbekistan, the formal state in this sense is absent. The state has retreated from the social and material provision as has already been shown through the experience of villagers in Pakhtabad. The collective farm, now a shirkat, is no longer a total social institution, but primarily a vehicle for the extraction of agricultural products by central government. It no longer provides meaningful salaries and services to its workers, but is at best a limited and intermittent a source of small parcels of land, often acquired through informal channels, for villagers to use to provide for themselves.

The post-independence government has produced its own national ideology, but this is qualitatively different from the Soviet project it replaces. Soviet state discourse constituted a formal structure in relation to which alternative informal spaces came into being, and gave these spaces a certain coherence, stability, and security. By contrast, the post-Soviet 'Idea of National Independence' is intended to legitimate the authoritarian rule of President Karimov. It is a practical tool for monitoring and controlling the population, for identifying dissent and 
intervening to suppress it. This ideology is founded upon a construction of an essentialised Uzbek cultural and spiritual heritage, a 'golden heritage' to which the nation is returning after decades of Soviet rule. Cultural authenticity has become a category which, far from providing a stable formal space in relation to which alternative informal spaces emerge, has produced a state of existential insecurity and vulnerability, where the actions and performance of citizens might be characterised as culturally inauthentic and therefore potentially subject to the intervention of the state security apparatuses (Rasanayagam 2011:121-179).

The post-Soviet state in Uzbekistan is experienced as the personalised and often arbitrary exercise of power. Commands and directives originate in the ministries in Tashkent, and are passed through the hierarchical structures of government administration. At the local level of practical implementation, however, they are often experienced as the extractive, extrajudicial actions of individual state officials, whether district governors, city public prosecutors, or traffic policemen. For example, state discourse extols the mahalla, a residential neighbourhood institution, as an embodiment of Uzbek tradition and a repository of the nation's spiritual heritage, and the post-independence government has revived and formalised the mahalla as a self governing institution with a locally elected leadership. In practical terms, however, central government uses the mahalla and its leadership as a means to monitor and control the population. It attempts to co-opt the bonds of neighbourhood sociality, the locally rooted norms of authority, reciprocity and obligation, as a tool of governance that extends beyond official state structures. Local district and city governors in their turn treat the institution of the mahalla committee as an extension of their own executive powers, even though in official legal terms the mahalla, as a self governing institution, is independent of the structures of government administration. They instruct mahalla leaderships to collect unpaid gas and electricity bills from their residents, or to force residents to pay unpaid taxes (Rasanayagam 2009). The local governor of one of the districts of Samarkand city in 2003 even ordered mahalla committee chairmen to organise the collection of scrap metal from residents in order to supply the needs of enterprises in his territory, threatening to fire chairmen who refused. ${ }^{6}$ In Pakhtabad village, I was told by teachers in 2004 that the previous year they had been forced to 'voluntarily donate' a day's pay in order to help finance the renovation of a local stadium by the district government. In Samarkand in 2003, a marshrutka taxi driver complained to me that the traffic police were stopping taxis and demanding 5000 sum (about $\$ 3$ at the time) to make up shortfalls in the

\footnotetext{
${ }^{6}$ Mahalla chairmen are elected by residents and district governors have no legal authority to directly appoint or dismiss them, although they do need to approve their appointment.
} 
non-payment of charges for exemptions from full military service.

These informal, extrajudicial interventions and extractions by state officials merge with the ubiquitous, everyday corruption of bribes and extractions for personal profit which are a part of almost every encounter with officials in Uzbekistan. The taxi driver who is forced to pay a levy towards shortfalls in charges for military service by a traffic policeman one day, might be forced to pay a bribe by a policeman on some pretext or other the next. The point is that the state itself is experienced as informal and personal.

\section{Discourses of corruption and the state}

During a conversation with a group of villagers in Pakhtabad, the topic turned to corruption and how a private farmer, present at the time, was being forced to pay one ton of wheat to court officials to avoid a possible prison sentence. One of the villagers declared that government officials were a Mafia, as they stole money from the state. People often used the idiom of the Mafia to express the exploitative activities of state officials. 'In Uzbekistan, the Mafia is the state' commented an entrepreneur who was complaining that he had given up trying to run a business because of the number of police and other officials demanding payoffs. 'Officials are queen bees who do nothing but feed on workers' complained another who was having trouble getting a bank loan without paying a bribe.

In post-Soviet Russia and Mongolia, Caroline Humphrey and David Sneath have identified pyramidal extraction chains which operate within the formal structures of state organs, like the Tax Inspectorate (Humphrey \& Sneath 2004). Villagers in Pakhtabad talked about similar chains, and claimed that district hokim (head of the district administration) pay bribes for their appointments and then demand similar payments from collective farm chairmen and enterprise heads under their authority. The sale of land in the village I described earlier is an expression of this. In 2000 I was told that a flour mill in a nearby town had been without a director for six months because the prospective candidate for the post was unable to come up with enough money for the bribe. Alisher Ilkhamov has reported similar claims about a district hokim in Fergana Province who was said to have paid $\$ 50,000$ for his appointment and then imposed an annual tribute of $\$ 10,000$ on each of the 4 collective farms, as well as smaller impositions on other enterprises, firms and shops in his jurisdiction. The hokim then gave the collective farm and enterprise managers freedom to raise the money any way they could, legally or illegally (Ilkhamov 2000).

Such chains or pyramids of corruption operating within official state structures is not of course a purely post-Soviet phenomenon. Ilya Zemtsov, writing about Soviet Azerbaijan in 
the 1960s and 1970s, has described hierarchical chains of corruption linking warehouse managers and collective farm brigadiers to ministers and First Secretaries in the Republican Communist Party. He reports that bribes were paid for senior appointments in the Communist Party and for such appointments as chairman of a collective farm, rector of an institute of higher education and head of certain enterprises. ${ }^{7}$ The 'tariff' was determined by demand which in turn depended on the income generating possibilities of the position (Zemtsov 1976:21f.).

Nancy Lubin, who conducted a study of work and income in Uzbekistan in the 1980's found that the bribes paid to enter higher education institutes reflected in part the illicit income earning possibilities on graduation. Although the highest official salaries were paid in heavy industry and for those jobs involving high levels of skill and training, such as air traffic controller, applications for agricultural and medical institutes, and the bribes paid to enter them, were higher than for institutes providing training for heavy industry. The bribes paid for appointment to jobs in services and agriculture were also higher which reflected the greater opportunities to earn unofficial incomes through embezzlement and plundering in these sectors. This picture is supported by villagers in Pakhtabad who claimed that during the Soviet period the highest bribes were needed to enter the History Faculty of the Pedagogical Institute, followed by the Medical and Agricultural Institutes. This was because the History Faculty was seen as a path for entry into the Communist Party and, as cotton was such an important crop for Uzbekistan, a career in agriculture was a means of securing senior posts in local government.

Although bribery and corruption were commonplace in the Soviet period, the subjective experience of it has changed, reflecting the changed nature of the state in Uzbekistan. In common with other post-Soviet societies, a widely shared perception is that while corruption existed in the past, it became much more widespread after socialism (Humphrey \& Sneath 2004; Sneath 2006). A former worker in the railway depot in the city of Andijan recollected that in the past it had been possible to complain to higher authorities in Tashkent or Moscow, but now these channels no longer work and the police, judiciary and local government officials all cooperate at the local level to cover each other. She recounted her own experience in the mid-1980s when she discovered that her supervisor had forged her signature on documents claiming that engines had been repaired in order to pocket the money himself. When she confronted him, he discredited her and had her committed to a mental

\footnotetext{
${ }^{7}$ Simis describes similar horizontal and vertical networks in the Soviet Union (1982:78-85)
} 
health institution. However, through contacts in the KGB who gave her a recording device, she managed to collect enough evidence to prove her case to higher authorities and eventually her boss was convicted and she was 'rehabilitated' in the local newspapers.

These recollections of corruption cannot be taken as representations of an objectively 'real' past. Memories are more productively understood as moral commentaries and responses to the individual's experience of the present (Berdahl 1999; Lambek 1996). But this is precisely what makes these accounts informative. They indicate an important shift in experience of the state in everyday lives. While corruption existed in the past, the Soviet Union is recalled as a stable and ultimately reliable state structure. As has been discussed in the previous section, the state provided for the material needs of citizens and enabled secure social spaces, even alternative spaces outside the authoritative state project as Yurchak has described, so long as citizens formally reproduced themselves as 'proper' Soviet citizens through an appropriate public performance. Much of what might be described as corrupt transactions were carried out through positively evaluated relationships of friendship and relatedness. By contrast, a number of anthropologists have observed that the de-socialisation and privatisation introduced with market reforms has been experienced by many in postSoviet space as 'wild capitalism' governed by Mafias and rackets and lacking in social relations (Anderson 2000; Humphrey 1999).

In Uzbekistan, I rarely heard people talk in terms of wild markets or capitalism. On the contrary, a common comparison made with neighbouring Central Asian states and Russia, especially by those engaged business or cross border trade, was that the Mafia and other rackets were much less prevalent in Uzbekistan. Instead, they frequently made comments to the effect that in Uzbekistan the Mafia was 'legal', that the state authorities themselves had a monopoly of Mafia activities. I would argue that the characterisation of the state itself as a Mafia is not so much an observation that corruption has increased in quantitative terms, but reflects a shift in how the state is experienced in everyday lives. The Soviet-era formal structures of material provision and support, and the ideological framework within which this was embedded, has disappeared, and the state has become personalised. The idiom of the Mafia expresses the oppressive and extractive nature of this experience, but at the same time, as the account of the 'sale' of land in Pakhtabad has shown, the personalised state can also open up space for negotiation by citizens to further their own projects and interests, something which is reflected in how people in Pakhtabad talk about corruption.

Tohirjon, the teacher I mentioned in previous sections, sometimes criticised the corrupt practices of officials. On one occasion he condemned nepotism in hiring and 
promotion at the local cotton processing plant. He said that this sort of corruption impeded the development of the country and he described bribery as a national illness. On another occasion, Tohirjon overheard his elder brother telling me about a case he had seen on television of a young man who had been given a heavy prison sentence for stealing some bread. 'Here collective farm officials steal much more, by that scale they should all be shot' his brother declared. Tohirjon intervened, saying that although his brother was so indignant about corruption, he would be the first to engage in it if it benefited his family and Tohirjon himself had bribed the Village Committee to grant his family poverty relief for six months. He had also bought fertiliser illegally from the manager of the collective farm warehouse, a common practice in the village.

Tohirjon distinguishes between earning money on the side through the use of resources available through work (levyi den'gi as he called it) and pora (the Uzbek word for bribery), although he claimed that he does not judge the morality of either situation and the buyer of the services is certainly not doing any wrong in his opinion. He described his actions of buying fertiliser (levyi den'gi for the warehouse manager) and bribing to be registered for poor relief as 'finding a way' (yo'l topmok) and 'entrepreneurship' (tadbirkorlik). One of his plans was to produce a crib to sell to students sitting the university entrance exams, and he had overheard a student at the vocational college where he taught offer another teacher $\$ 100$ to sit one of his exams for him. That teacher refused, asking \$200, and Tohirjon told me he would be willing to do it if the student's parents could protect him from the authorities. He viewed these activities as business or money making ventures, similar to the private university entrance test preparation courses he offered, or growing crops on his plots for sale. He did not seem to distinguish between his legal and illegal ventures, they were all part of his household money making strategy. I asked him if he considered producing the cribs as corruption and he replied that it was a 'little corruption', it did not hurt anyone. When I asked if it was fair on the students who did not cheat, he said 'it is a time for entrepreneurship'. Intelligent students who were not capable enough to get a crib would not succeed in the real world anyway, since now money is the only important thing and stupid people with money are the ones who succeed.

How should we interpret these contradictory attitudes, and also the other practices of 'corruption' described above, such as the extra-legal extractions of traffic policemen. They might simply express an instrumental self interest, which views the appropriations of others as corrupt, whereas one's own actions are characterised as doing the best for one's self, family or community. Alternatively, the contrasting judgements might be produced by the 
application of different moral frames which are invoked contextually. Cynthia Werner has argued that moral evaluations of the legitimacy of a transaction are contextually determined, depending on the subject position of the person making the judgement and the relation between the giver and the receiver, so that distinctions between gifts and bribes are blurred (Werner 2000). Abel Polese similarly explores the contextual morality and shifting categories of gift and bribe, where judgements are made with reference to the retreat of the state from the provision of realistic levels of pay and social services, and the strategies for survival this makes necessary (Polese 2008). David Sneath, discussing corruption in Mongolia, develops this perspective further when he argues that transfers of goods and assistance can productively be understood as materialisations of social relations, positively evaluated when they express ties of obligation and expectation within networks of kinship and friendship, and illegitimate when associated with instrumental, impersonal, 'market' exchanges (Sneath 2006).

I argue that these discourses also emerge from a wider experience of the informalisation of the state and of lifeworlds. Alongside condemnation of state officials as Mafia, they can be understood as a moral critique of the present situation, in contrast with the Soviet past, and a bitter resignation to the demands of the present. Castells and Portes have argued that the informal economy only makes sense in relation to formal structures of state regulation. The Soviet state provided a formal economic and ideological structure which enabled particular dynamics and formations of informal exchange and sociality. In present day Uzbekistan, the state itself has become informalised and personalised. What we might call the informal economy is an expression of this more general informalisation of lifeworlds, so that in an important sense the informal is all that there is. 


\section{References}

Abashin, S. 1997. Sotsial'nye korni sredneaziatskogo islamizma (na primere odnogo seleniya). In Identichnost' $i$ konflikt v postsovetskikh gosudarstvakh (eds) M.B. Olcott, V. Tishkov \& A. Malashenko. Moscow: Carnegie Endowment for International Peace.

Abrams, P. 1988. Notes on the difficulty of Studying the State. Journal of Historical Sociology 1, 58-89.

Anderson, D. 2000. Surrogate Currencies and the 'Wild Market' in Central Siberia. In The Vanishing Rouble: Barter Networks and Non-Monetary Transactions in Post-Soviet Societies (ed.) P. Seabright. Cambridge: Cambridge University Press.

Berdahl, D. 1999. '(N)Ostalgie' for the Present: Memory, Longing, and East German Things. Ethnos 64, 192-211.

Carrithers, M. 2005. Anthropology as a Moral Science of Possibilities. Current Anthropology 46, 433-456.

Castells, M. \& A. Portes. 1989. World Underneath: The Origins, Dynamics, and Effects of the Informal Economy. In The Informal Economy: Studies in Advanced and Less Developed Countries (eds) A. Portes, M. Castells \& L.A. Benton. Baltimore The Johns Hopkins University Press.

Grossman, G. 1977. The Second Economy of the USSR. Problems of Communism 26, 25-40.

Gupta, A. 1995. Blurred Boundaries: The Discourse of Corruption, the Culture of Politics, and the Imagined State. American Ethnologist 22, 375-402.

Hart, K. 1973. Informal Income Opportunities and Urban Employment in Ghana. Journal of Modern African Studies 11, 61-89.

- 1992. Market and State after the Cold War: The Informal Economy Reconsidered. In Contesting Markets: Analysis of Ideology, Discourse and Practice (ed.) R. Dilley. Edinburgh: Edinburgh University Press.

Harvey, P. 2005. The Materiality of State-Effects: An Ethnography of a Road in the Peruvian Andes. In State Formation: Anthropological Perspectives (eds) C. Krohn-Hansen \& K.G. Nustad. London Pluto Press.

Hoffmann, D.L. 2003. Stalinist Values: The Cultural Norms of Soviet Modernity, 1917-1941. Ithaca: Cornell University Press.

Humphrey, C. 1998. Marx Went Away but Karl Stayed Behind. Ann Arbor: University of Michigan Press.

—. 1999. Traders, "Disorder", and Citizenship Regimes in Provincial Russia. In Uncertain Transition: Ethnologies of Change in the Postsocialist World (eds) M. Burawoy \& K. Verdery. Lanham: Rowman \& Littlefield.

Humphrey, C. \& D. Sneath. 2004. Shanghaied by the Bureaucracy: Bribery and Post-Soviet Officialdom in Russia and Mongolia. In Between morality and the Law: Corruption, Anthropology and Comparative Society (ed.) I. Pardo. Aldershot Ashgate.

Ilkhamov, A. 1998. Shirkats, Dekhqon Farmers and Others: Farm Restructuring in Uzbekistan. Central Asian Survey 17, 539-560.

—. 2000. The 'Uzbek Model' of Farm Economy: Formal and Informal Aspects. Paper presented to the Informal Economies and Civil Society in Post-Soviet Eurasia, Centre for Russian Research and East European Studies, University of Michigan, 2000.

Johnson, S., D. Kaufmann \& A. Shleifer. 1997. The Unofficial Economy inTransition. Brookings Papers on Economic Activity 1997 No. 2.

Kandiyoti, D. 1999. Poverty in Transition: An Ethnographic Critique of Household Surveys in Post-Soviet Central Asia. Development and Change 30, 499-524. 
—. 2002. How Far do Analyses of Postsocialism Travel? The Case Of Central Asia. In Postsocialism: Ideals, Ideologies and Practices in Eurasia (ed.) C. Hann. London: Routledge.

—. 2003. The Cry for Land: Agrarian Reform, Gender and Land Rights in Uzbekistan. Journal of Agrarian Change 3, 225-256.

Kharkhordin, O. 1999. The Collective and the Individual in Russia: A Study of Practices. Berkeley: University of California Press.

Kotkin, S. 1995. Magnetic Mountain: Stalinism as a Civilization. Berkeley: University of California Press.

Kurkchiyan, M. 2000. The Transformation of the Second Economy into the Informal Economy. In Economic Crime in Russia (eds) A. Ledeneva \& M. Kurkchiyan. London: Kluwer Law International.

Lambek, M. 1996. The Past Imperfect: Remembering as Moral Practice. In Past Tense: Cultural Essays in Trauma and Memory (eds) P. Antze \& M. Lambek. New York: Routledge.

Ledeneva, A. 1998. Russia's Economy of Favours: Blat, Networking, and Informal Exchange. Cambridge: Cambridge University Press.

Lubin, N. 1984. Labour and Nationality in Soviet Central Asia. Princeton: Princeton University Press.

Mitchell, T. 1999. Society, Economy and the State Effect. In State/Culture: State-Formation after the Cultural Turn (ed.) G. Steinmetz. Ithaca: Cornell University Press.

Mollona, M. 2005. Factory, Family and Neighbourhood: The Political Economy of Informal Labour in Sheffield. Journal of the Royal Anthropological Institute (N.S.) 11, 527 548.

Polese, A. 2008. 'If I receive it, it is a gift; if I demand it, then it is a bribe': On the Local Meaning of Economic Transactions in Post-Soviet Ukraine. Anthropology in Action 15, 47-60.

Poliakov, S.P. 1992. Everyday Islam: Religion and Tradition in Rural Central Asia. London: M. E. Sharpe.

Rasanayagam, J. 2002. Spheres of Communal Participation: Placing the State within Local Modes of Interaction in Rural Uzbekistan. Central Asian Survey 21, 55-70.

- 2003. Market, State and Community in Uzbekistan: Reworking the Concept of the Informal Economy: Max Planck Institute for Social Anthropology Working Paper No. 59.

-. 2009. Morality, Self and Power: The Idea of the Mahalla in Uzbekistan. In The Anthropology of Moralities (ed.) M. Heintz. Oxford: Berghahn Books.

-. 2011. Islam in Post-Soviet Uzbekistan: The Morality of Experience. Cambridge: Cambridge University Press.

Rodgers, P. \& C.C. Williams. 2009. The Informal Economy in the Former Soviet Union and in Central and Eastern Europe. International Journal of Sociology 39, 3-11.

Sik, E. 1992. From the Second Economy to the Informal Economy. Journal of Public Policy 12, 153-175.

Sneath, D. 2006. Transacting and Enacting: Corruption, Obligation and the Use of Monies in Mongolia. Ethnos 71, 89-112.

Treml, V. \& M. Alexeev. 1994. The Growth of the Second Economy in the Soviet Union and Its Impact on the System. In The Postcommunist Economic Transformation: Essays in Honor of Gregory Grossman (ed.) R. Campbell. Boulder: Westview Press.

Trevisani, T. 2009. The Reshaping of Inequality in Uzbekistan: Reforms, Land and Rural Incomes. In The Political Economy of Rural Livelihoods in Transition: Land, Peasants and Rural Poverty in Transition (ed.) M. Spoor. Abingdon: Routledge. 
1

2

3

4

5

6

7

8

9

10

11

12

13

14

15

16

17

18

19

20

21

22

23

24

25

26

27

28

29

30

31

32

33

34

35

36

37

38

39

40

41

42

43

44

45

46

47

48

49

50

51

52

53

54

55

56

57

58

59

60

Werner, C. 2000. Gifts, Bribes and Development in Post-Soviet Kazakstan. Human Organization 59, 11-22.

White, J.B. 1994. Money Makes Us Relatives: Women's Labor in Urban Turkey Austin: University of Texas Press.

Yurchak, A. 2006. Everything was Forever, until it was No More: The Last Soviet Generation. Princeton: Princeton University Press.

Zemtsov, I. 1976. Partia ili Mafia Paris: Les Éditeurs Réunis.

Zinoviev, A. 1984. The reality of communism (trans.) C. Janson. London: Gollancz. 